DOI: 10.22616/REEP.2019.011

\title{
Role of School Principals in High Achievement of Students
}

\author{
Agnese Malere $^{1}$ Mg. sc. admin.; Antra Ozola ${ }^{2}$ Dr. sc. admin. \\ University of Latvia, Latvia \\ malere.agnese@lu.lv1; antra.ozola@lu.lv²
}

\begin{abstract}
The role of the principal in a school is critical because a principal is not only an administrator, but also a manager, initiator of various processes and, ideally, also a school leader who furthers various processes in the school and facilitates high achievement among the students. It is therefore important to study the role of the principal and how the principal can facilitate student achievement. The aim of the research study is to carry out a comparative analysis of data from several countries to find out the factors associated with the activities of the principal (directions of professional activity, factors created by the school culture and environment) that facilitate high achievement among students. Data from a survey conducted among school principals within the IEA PIRLS 2016 study have been used for the analysis. IEA PIRLS (Progress in International Reading Literacy Study) is a large international comparative study of the reading literacy of grade 4 students. 50 countries, including Latvia, participated in it in 2016. In the article, the data for Latvia are compared with several geographically, culturally and historically close countries, such as Denmark, Germany, Poland, Lithuania, Russia, Finland and Sweden. The results of the research study suggest that the principal has a significant role in the facilitation of the students' achievement, but the association is indirect. The principal furthers various processes in the school, aids the teachers in their professional activity, and builds an environment in the school which facilitates achievement among the students.
\end{abstract}

Keywords: school principals, high student achievement, PIRLS, reading literacy, school education.

\section{Introduction}

The head of an educational establishment (the principal) is the main administrator and manager of a school. As research studies conducted in various countries (Dhuey, Smith, 2014; O'Malley, Long, King, 2015) suggest, the experience of the principal is indirectly associated with the performance of the teachers and students. Furthermore, the greater autonomy of schools and the higher responsibility of the principals would be necessary. A new Cabinet regulation on the national standard for basic education has recently been drafted in Latvia and includes provisions for greater autonomy of schools and higher levels of responsibility for the principals, e.g., "an educational establishment shall build a learning environment which is physically and emotionally secure, it shall facilitate the student's acquisition of social and emotional skills and learning, and it shall be tailored to the diverse learning and development needs of every student", "an educational establishment shall, as early as possible, initially ascertain the basic skills and the learning needs of the student and monitor the growth of each student [...], by giving each student wider opportunities for full involvement in the process of learning" (MK noteikumu projekts..., 2018). This suggests that a school principal should build a school environment in which the aims set with regard to the achievement of the students are attained, by taking care not only of a successful course and organisation of the process of learning, but also of individual approach to each student in consideration of their individual skills and needs. Although principals further various processes in the school, they should be ready for new challenges because the approach to the content of learning will change in Latvia in 2020. Consequently, it is important to understand the current situation and improve the understanding of what is currently working successfully in schools and what is to be improved. Principals as the main manager at school are responsible for managing the major administrative tasks. The most important competences of principals for performing the administrative work are management competence, competence of strategic thinking, communication skills, methodological competence and intellectual competence (Andersone, 2013). Nevertheless, administrative work is one part of principals' work. Principals have the most complex roles in education.

The aim of the research study is to carry out a comparative analysis of data from several countries to find out the factors associated with the activities of the principal (directions of professional activity, factors created by the school culture and environment) that facilitate high achievement among students. 


\section{Methodology}

Data from the IEA (International Association for the Evaluation of Educational Achievement) PIRLS study (the Progress in International Reading Literacy Study) conducted in 2016 have been used in the research study. The results of a survey conducted among the principals of schools in Latvia have been used as the source data, and they are associated with the description of the school, the readiness of the students for learning to read, the experience and education of the principals as well as the expectations of the principals regarding the performance of the students.

The target population of the PIRLS study is students of the 4th grade. Students, their parents, teachers, and also the principals were the respondents in the survey. 150 schools from Latvia participated in the IEA PIRLS 2016 study. Each school principal had to complete a questionnaire containing various questions related to the school and the principal himself/herself. The principals were asked for a description of the school and about the learning times, resources and technologies, the attitude of the school to learning achievement, discipline and security/safety in the school, the readiness of the students for learning to read, reading at school, the experience and education of the principals, and national questions were also asked, such as what support systems are available in the school, what expectations the principals have with regard to the performance of the students and the teachers, and also questions about students with special needs.

The data analysis was performed using the statistical software IBM SPSS 22 and IEA IDB Analyzer programmes. The research methods used in the study are literature analysis and secondary data analysis and analysis of data obtained in IEA PIRLS 20116 study. Descriptive statistics (frequency, means, standard errors and percentages) and correlation analysis was performed. For replication purposes or further analysis, the PIRLS databases are freely available on the website of the IEA's TIMSS and PIRLS International Study Centre.

\section{Results and Discussion}

The questionnaire for schools in the Progress in International Reading Literacy Study (PIRLS) contains various questions for school principals regarding the schools managed by them as well as about the principals themselves. The questionnaire includes questions regarding the experience of the principal in their official capacity and the acquired education. The principals of schools in Latvia have an average of 16 years of experience in the position of the head of an educational establishment, and this is above the average of 10 years for the countries participating in the study. School principals in Lithuania also have an average of 16 years in the position of a school principal. School principals in Latvia and Lithuania have the highest average length of service as heads of schools, but the school principals in Germany and Sweden have the shortest lengths of service (an average of 9 years) among the countries of comparison (Table 1).

Comparatively in all of the countries participating in the PIRLS, $14 \%$ of the students go to schools whose principals have more than 20 years of experience in the capacity of the head of an educational establishment, $31 \%$ of the students have principals whose length of service exceeds 10 years, but is not above 20 years. The principals of $27 \%$ of the students, in their turn, have more than 5, but less than 10 years of work experience, but the principals of $28 \%$ of the students have a comparatively small working experience (less than 5 years). There are comparatively less students in Latvia (17\%) who have principals with a smaller length of service (less than 5 years), $14 \%$ of the students have principals with more than 5, but less than 10 years of working experience. In line with the average for the countries participating in the PIRLS, Latvia also has $31 \%$ of the students who go to schools with principals whose work experience in the capacity of the school principal is more than 10, but less than 20 years. Since, out of all the countries participating in the PIRLS 2016 study, the school principals in Latvia (and also Lithuania) had the greatest length of service, $38 \%$ of the students in Latvia go to schools with principals whose work experience in this official position is 20 or more years.

Based on the analysis of the results of the study, it can be acknowledged that the achievement of the students have no direct correlation with the work experience (length of service) of the principals. This is also proven by other studies where the obtained data suggest that the experience of the principals has no close correlation with the achievement of the students (Brockmeier, Starr, Green, Pate, Leech, 2013). 
Work experience of school principals (Mullis et al., 2016)

\begin{tabular}{|c|c|c|c|c|c|c|c|c|c|c|c|}
\hline \multirow{3}{*}{\begin{tabular}{|l}
\multicolumn{1}{c}{ Country } \\
Denmark \\
\end{tabular}} & \multicolumn{8}{|c|}{$\begin{array}{l}\text { Percent of students by principals' years of } \\
\text { experience as a principal }\end{array}$} & \multirow{2}{*}{$\begin{array}{l}\text { Average } \\
\text { years of } \\
\text { experience } \\
\text { as a } \\
\text { principal }\end{array}$} & \multirow{2}{*}{\multicolumn{2}{|c|}{$\begin{array}{c}\text { Average } \\
\text { achievement } \\
\text { of the } \\
\text { students on } \\
\text { the national } \\
\text { scale }\end{array}$}} \\
\hline & \multicolumn{2}{|c|}{$\begin{array}{l}20 \text { years or } \\
\text { more }\end{array}$} & \multicolumn{2}{|c|}{$\begin{array}{c}\text { At least 10, } \\
\text { but not } \\
\text { more than } \\
20\end{array}$} & \multicolumn{2}{|c|}{$\begin{array}{c}\text { At least } 5 \text {, } \\
\text { but not } \\
\text { more than } \\
10\end{array}$} & \multicolumn{2}{|c|}{$\begin{array}{c}\text { Less than } 5 \\
\text { years }\end{array}$} & & & \\
\hline & 10 & $(2.5)$ & & $(3.5)$ & & $(3.1)$ & 30 & (3.6) & $10 \quad(0.5)$ & 547 & $(2.1)$ \\
\hline Finland & 20 & (3.6) & 33 & $(4.0)$ & & (3.8) & 23 & $(3.2)$ & $12 \quad(0.7)$ & 566 & (1.8) \\
\hline Germany & 12 & $(2.4)$ & 29 & $(3.8)$ & 24 & (3.0) & 35 & $(3.5)$ & $9 \quad(0.6)$ & 537 & $(3.2)$ \\
\hline Latvia & 38 & (4.0) & 31 & (3.6) & 14 & (3.0) & 17 & (3.2) & 160.8 & 558 & 1.7 \\
\hline Lithuania & 41 & (3.7) & 34 & (3.6) & 10 & $(2.3)$ & 15 & $(2.7)$ & $16 \quad(0.7)$ & 548 & $(2.6)$ \\
\hline Poland & 21 & (3.7) & 36 & (3.) & 22 & (3. & & (3.) & $(0.7)$ & 565 & $(2$. \\
\hline Russia & 15 & (2.4) & 32 & (3.3) & 26 & (2.9) & 26 & (3.5) & $11 \quad(0.6)$ & 581 & (2.2) \\
\hline Sweden & 10 & (3.2) & & $(4.0)$ & 32 & (4.4) & 30 & (3.6) & $9 \quad(0.9)$ & 555 & (2.4) \\
\hline International average & 14 & $(0.4)$ & 31 & $(0.5)$ & 27 & $(0.5)$ & 28 & $(0.5)$ & $10 \quad(0.1)$ & 500 & \\
\hline
\end{tabular}

Even if the experience of the principal has a correlation with the student achievement, it is very small (Dhuey, Smith, 2014). This does not confirm the view that a more experienced principal facilitates the achievement of the students and a less experienced principal may lower it. For example, school principals in Latvian and Lithuania have an average of 16 years of working experience, but the average reading literacy achievement of grade 4 students in Latvia had the score of 558 points in the PIRLS 2016 study, whereas the score for Lithuania was 548 points (statistically significantly lower than for Latvia). In Russia, the average length of service of the school principals was 11 years, but the average reading literacy achievement of their grade 4 students had the internationally highest score of 581 points. The average length of service of the school principals in Germany and Sweden was 9 years, but the achievement of the students in these countries did not differ. Respectively, the average reading literacy achievement of the Swedish students had the score of 555 points, but Germany had a considerably lower score of 537 points.

The correlation between the length of service of the Latvian school principals and the reading literacy achievement of their grade 4 students in the school managed by them is shown in Table 2, depending on the type of school. It can be seen that the principals of upper and lower secondary schools in Latvia have a higher average length of service in their official position in the school currently managed by them, and a higher length of service of the principal correlates with higher achievement of the students. Although statistically significant, this correlation is weak. The heads of the Latvian primary schools, in their turn, have been holding the office for shorter periods, and the differences in the time spent in the position of a school principal are not as great for the heads of the primary schools as for the principals of the other schools.

Table 2

Correlation between length of service of principals and achievement of students depending on type of school in Latvia

\begin{tabular}{|l|c|c|c|}
\hline \multicolumn{1}{|c|}{ Type of school } & $\begin{array}{c}\text { Principal's length of } \\
\text { service in the current } \\
\text { school (years) }\end{array}$ & Standard deviation & $\begin{array}{c}\text { Correlation with } \\
\text { achievement }\end{array}$ \\
\hline Upper secondary schools & 14.5 & 9.4 & $0.24^{*}$ \\
\hline Lower secondary schools & 15.0 & 10.1 & $0.16^{*}$ \\
\hline Primary schools & 9.6 & 5.0 & -0.24 \\
\hline * Significant correlation & \multicolumn{2}{l}{} \\
\hline
\end{tabular}

Ninety-two percent of the students in Latvia go to schools managed by principals holding a master's or doctorate degree, whereas $8 \%$ of the students go to an educational establishment managed by a principal with a baccalaureate or an equal degree only. Compared to other countries, Latvia is one of the countries with a comparatively high percentage of students whose school principals have a master's or a doctorate degree 
(Table 3). In Latvia, the level of correlation between the achievement of the students and the level of education of the school principal is 0.26 (Pearson's correlation coefficient), and it is statistically significant.

Table 3

Formal education of school principals (Mullis et al., 2016)

\begin{tabular}{|c|c|c|c|c|c|c|}
\hline \multirow[b]{2}{*}{ Country } & \multicolumn{3}{|c|}{$\begin{array}{c}\text { Percent of students by principal } \\
\text { education level }\end{array}$} & \multicolumn{2}{|c|}{ Current requirements } & \multirow[b]{2}{*}{$\begin{array}{c}\text { Average } \\
\text { student } \\
\text { reading } \\
\text { achievement }\end{array}$} \\
\hline & $\begin{array}{c}\text { Completed } \\
\text { master's } \\
\text { or } \\
\text { doctorate } \\
\text { degree }\end{array}$ & $\begin{array}{c}\text { Completed } \\
\text { bachelor's } \\
\text { degree or } \\
\text { equivalent }\end{array}$ & $\begin{array}{c}\text { Did not } \\
\text { complete } \\
\text { bachelor's } \\
\text { degree }\end{array}$ & $\begin{array}{c}\text { Teaching } \\
\text { experience }\end{array}$ & $\begin{array}{c}\text { Completion } \\
\text { of } \\
\text { specialized } \\
\text { school } \\
\text { leadership } \\
\text { training } \\
\text { program }\end{array}$ & \\
\hline Denmark & $18 \quad(2.8)$ & $73 \quad(3.5)$ & $9 \quad(2.3)$ & No & No & $547 \quad(2.1)$ \\
\hline Finland & $89 \quad(2.3)$ & $10 \quad(2.2)$ & $1 \quad(0.5)$ & Yes & Yes & $566 \quad(1.8)$ \\
\hline Germany & $90 \quad(1.3)$ & $\begin{array}{ll} & (0.8) \\
\end{array}$ & $9 \quad(1.6)$ & Yes & No & $537 \quad(3.2)$ \\
\hline Latvia & $92 \quad(2.0)$ & (2.0) & $\begin{array}{ll}0 & (0.0) \\
\end{array}$ & Yes & No & 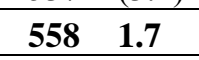 \\
\hline Lithuania & $(4.0)$ & $(4.0)$ & $0 \quad(0.0)$ & Yes & No & $548 \quad(2.6)$ \\
\hline Poland & $(0.7)$ & $(0.7)$ & $0 \quad(0.0)$ & - & - & $565 \quad(2.1)$ \\
\hline Russian Federation & $90 \quad(2.2)$ & $(2.2)$ & $0 \quad(0.0)$ & Yes & Yes & $581 \quad(2.2)$ \\
\hline Sweden & $29 \quad(4.1)$ & $(4.1)$ & $4 \quad(1.7)$ & No & Yes & $555 \quad(2.4)$ \\
\hline International average & $48 \quad(0.4)$ & $45 \quad(0.4)$ & $7 \quad(0.2)$ & & & 500 \\
\hline
\end{tabular}

The education of the heads of the Latvian schools by the types of schools can be seen in Table 4 . An absolute majority of the heads of the primary schools in Latvia have a master's degree, approximately $2 \%$ of the school principals in Latvia hold a doctorate degree, and, compared to other types of schools, the principals of the lower secondary schools more often have a baccalaureate degree.

Table 4

Formal education of heads of Latvian schools (by types of schools) and corresponding average achievement of students

\begin{tabular}{|l|c|c|c|c|c|c|}
\hline \multirow{2}{*}{$\begin{array}{c}\text { Acquired } \\
\text { education }\end{array}$} & \multicolumn{2}{|c|}{ Upper secondary schools } & \multicolumn{2}{c|}{ Lower secondary schools } & \multicolumn{2}{c|}{ Primary schools } \\
\cline { 2 - 7 } & $\begin{array}{c}\text { Percent of } \\
\text { principals }\end{array}$ & $\begin{array}{c}\text { Average } \\
\text { student } \\
\text { achievement }\end{array}$ & $\begin{array}{c}\text { Percent of } \\
\text { principals }\end{array}$ & $\begin{array}{c}\text { Average } \\
\text { student } \\
\text { achievement }\end{array}$ & $\begin{array}{c}\text { Percent of } \\
\text { principals }\end{array}$ & $\begin{array}{c}\text { Average } \\
\text { student } \\
\text { achievement }\end{array}$ \\
\hline Baccalaureate & 8.9 & 556 & 30.9 & 522 & 3.7 & - \\
\hline Master's & 89.2 & 556 & 66.3 & 535 & 96.3 & 550 \\
\hline Doctorate & 2.0 & 570 & 2.8 & 562 & - & - \\
\hline
\end{tabular}

The researchers indicate that the principal has an indirect influence on the student achievement (Soehner, Ryan, 2015). Furthermore, there are research studies which confirm that the principal has significant influence on the student's results in mathematics and reading (Dhuey, Smith, 2014). The principal may indirectly influence the achievement of the students by supporting the work of the teachers. A study conducted in Germany revealed that the involvement of the principal is a trigger for school innovations. If there is more involvement from the principal, the teachers become more creative (Koch, Binnewies, Dormann, 2015). The Swedish researcher Leo Ulf (2015), in his turn, points out an issue that principals try to get involved in the process of learning and be a part of it, but there is not always enough time for it, and observing the lessons of the teachers is not systematic. Principals should be closer to the teaching and learning process, and the internal organisation of the school should be developed in order to facilitate learning (Ulf, 2015).

In the survey conducted within the PIRLS 2016 study, the principals were also asked questions like "Does your school provide a place where students can work on their schoolwork before or after school?" and "Is someone available to assist them with their schoolwork?" $93 \%$ of the school principals in Latvia specified that their school provided a place where the students can do their homework before or after the lessons, and, moreover, $94 \%$ of the principals specified that the school also had a person who helps 
the students with their homework (Table 5). The analysis of the responses of the principals to the above questions leads to a conclusion that the students have opportunities for doing their homework before or after their lessons. Thus, the school provides a place where the students can do it. This might be explained by the extended school day groups where there are teachers who help the students after the lessons to do their homework as well as carry out other activities. It should be noted that most of the students in Latvia go to schools in which the principals provide a place for doing their homework and a person who helps the students to do it. It can be seen that the reading achievement level is higher among the grade 4 students of the schools with no place or person who helps to do homework. Apparently, no such service is offered in cases when it is not necessary.

However, the situation is not similar in all countries (Table 5). For most of the countries selected for the comparison, the average reading literacy achievement of the grade 4 students is higher in the schools where the students have no access to a person who would help them in doing their homework. The situation is also similar in Poland where the achievement of the students is higher in the schools for which the principals have specified that there was neither a place in the school where a student could do their homework before or after the lessons not a person to help the student with doing it. Compared to the other nearest neighbouring countries of Latvia, such results are not unambiguous. In Russia and Finland, the average achievement of the students is higher in the schools for which the principals have specified that there is a place in the school where the students can do their homework before or after their lessons. In Germany, the student achievement does not change depending on such opportunity. Conversely, in Poland, Lithuania, Latvia, Russia and Sweden, the students have higher average scores in the schools for which the principals have specified that the school has no person who helps the students with their homework. Only in Denmark, the average achievement of the students is higher in the schools where there is a person who helps them do their homework. Nevertheless, it cannot be stated that the average achievement of the students is statistically significantly different in these groups in all the countries.

Table 5

Average achievement of students depending on school support measures available to them for doing homework

\begin{tabular}{|c|c|c|c|c|c|c|c|c|}
\hline \multirow{3}{*}{ Country } & \multicolumn{4}{|c|}{$\begin{array}{l}\text { Does your school provide a place } \\
\text { where students can work on their } \\
\text { schoolwork before or after school? }\end{array}$} & \multicolumn{4}{|c|}{$\begin{array}{l}\text { Is someone available to assist them with their } \\
\text { schoolwork? }\end{array}$} \\
\hline & \multirow[t]{2}{*}{ Yes } & \multirow[t]{2}{*}{ No } & \multicolumn{2}{|c|}{$\begin{array}{c}\text { Students average } \\
\text { achievement }\end{array}$} & \multirow[t]{2}{*}{ Yes } & \multirow[t]{2}{*}{ No } & \multicolumn{2}{|c|}{$\begin{array}{c}\text { Students average } \\
\text { achievement }\end{array}$} \\
\hline & & & Yes & No & & & Yes & No \\
\hline Denmark & $\begin{array}{c}60 \% \\
(4.07) \\
\end{array}$ & $\begin{array}{c}40 \% \\
(4.07) \\
\end{array}$ & 548 & 545 & $71 \%(5.63)$ & $\begin{array}{c}29 \% \\
(5.63) \\
\end{array}$ & 552 & 541 \\
\hline Germany & $\begin{array}{l}72 \% \\
(4.07) \\
\end{array}$ & $\begin{array}{c}28 \% \\
(4.07) \\
\end{array}$ & 536 & 536 & $98 \%(1.20)$ & $2 \%(1.20)$ & 536 & 539 \\
\hline Poland & $\begin{array}{c}89 \% \\
(3.48)\end{array}$ & $\begin{array}{c}11 \% \\
(3.48)\end{array}$ & 564 & 571 & $97 \%(2.14)$ & $3 \%(2.14)$ & 564 & 582 \\
\hline Lithuania & $\begin{array}{l}77 \% \\
(4.7) \\
\end{array}$ & $\begin{array}{l}23 \% \\
(4.7)\end{array}$ & 550 & 545 & $95 \%(2.61)$ & $5 \%(2.61)$ & 548 & 561 \\
\hline Latvia & $\begin{array}{l}93 \% \\
(1.35)\end{array}$ & $\begin{array}{c}7 \% \\
(1.35)\end{array}$ & 556 & 567 & $94 \%(2.55)$ & $9 \%(2.55)$ & 554 & 568 \\
\hline $\begin{array}{l}\text { Russian } \\
\text { Federation } \\
\end{array}$ & $\begin{array}{l}46 \% \\
(5.49) \\
\end{array}$ & $\begin{array}{l}54 \% \\
(5.49) \\
\end{array}$ & 589 & 573 & $94 \%(4.07)$ & $6 \%(4.07)$ & 588 & 598 \\
\hline Finland & $\begin{array}{c}60 \% \\
(5.97)\end{array}$ & $\begin{array}{c}40 \% \\
(5.97)\end{array}$ & 568 & 561 & $78 \%(5.88)$ & $\begin{array}{c}22 \% \\
(5.88)\end{array}$ & 568 & 568 \\
\hline Sweden & $\begin{array}{c}69 \% \\
(5.63) \\
\end{array}$ & $\begin{array}{c}31 \% \\
(5.63) \\
\end{array}$ & 556 & 553 & $98 \%(1.33)$ & $2 \%(1.33)$ & 555 & 559 \\
\hline
\end{tabular}

As already stated before, a principal has an indirect influence on the learning achievement of students. Research studies suggest that the work of a principal influences the results of students in mathematics and reading (Dhuey, Smith, 2014) as well as has a significant role in the diversification or change of the approaches in the acquisition of reading literacy in the school (Puzio, Newcomer, Goff, 2015). M. Purvins, who has analysed the factors which influence the learning achievement in the schools of 
general education in Latvia, states that several hundreds of factors that influence the achievement of students can be found in the theoretical sources, but there is no consensus among the researchers regarding the extent of such influences and whether the factors have positive or negative influences on the achievement of the students. M. Purvins highlights three factors as the most significant: cases of missing school, number of students in the school and the classroom, age of starting education (Purvins, 2017). When viewing the influence of the school on the achievement of the students, the preparedness of the students upon starting their 1 st year at schooling should also be taken into account.

With the help of school principals, the percentage of students able to complete certain tasks associated with reading literacy (ability to recognise most of the letters of the alphabet, read some words or sentences, read a story, write letters of the alphabet or some words) at the start of their 1st year at school was determined in the PIRLS 2016 study. More than a half of the Latvian students have the above skills upon starting their 1st year at school. This is related with the skills the child is taught in the family and the skills children acquire in a pre-school educational establishment. In Lithuania, for example, only $8 \%$ of students start their 1 st year in a school where more than $75 \%$ of the students have the said early skills (Table 6). In Latvia, schools often collaborate with the nearby pre-school educational establishments and thus facilitate the attraction of grade 1 students. It is important to have a closer collaboration between teachers of grade 1 and pre-school teachers. Moreover, not only to assure a more successful adaptation of the grade 1 students in the school, but also to improve the preparedness of the future students for school, and also to make sure that, upon starting their school years, students have acquired the skills the school expects from them. The key organiser in the facilitation of this collaboration is the principal who promotes and organises these collaboration opportunities.

Table 6

Schools where students enter the primary grades with literacy skills (Mullis et al., 2016)

\begin{tabular}{|c|c|c|c|c|c|c|}
\hline \multirow{3}{*}{$\begin{array}{l}\text { Country } \\
\text { Latvia }\end{array}$} & \multicolumn{2}{|c|}{$\begin{array}{l}\text { Schools where more than } \\
75 \% \text { enter with skills }\end{array}$} & \multicolumn{2}{|c|}{$\begin{array}{c}\text { Schools where } 25-75 \% \\
\text { enter with skills }\end{array}$} & \multicolumn{2}{|c|}{$\begin{array}{l}\text { Schools where less than } \\
25 \% \text { enter with skills }\end{array}$} \\
\hline & $\begin{array}{l}\text { Percent of } \\
\text { students }\end{array}$ & $\begin{array}{c}\text { Average } \\
\text { achievemen } \\
t\end{array}$ & $\begin{array}{c}\text { Percent of } \\
\text { students }\end{array}$ & $\begin{array}{c}\text { Average } \\
\text { achievemen } \\
t\end{array}$ & $\begin{array}{l}\text { Percent of } \\
\text { students }\end{array}$ & $\begin{array}{c}\text { Average } \\
\text { achievement }\end{array}$ \\
\hline & $53 \quad(4.7)$ & $560 \quad(2.8)$ & $44 \quad(4.6)$ & $557 \quad(2.9)$ & $3 \quad(1.3)$ & $525 \quad(12.5)$ \\
\hline Denmark & $36 \quad(4.1)$ & $553 \quad(3.6)$ & $59 \quad(4.1)$ & $546 \quad(2.9)$ & $5 \quad(1.6)$ & $530 \quad(9.0)$ \\
\hline Sweden & $23 \quad(3.8)$ & $569 \quad(5.1)$ & $72 \quad(4.1)$ & $553 \quad(2.6)$ & $5 \quad(1.8)$ & $519 \quad(8.5)$ \\
\hline Poland & $14 \quad(3.3)$ & $558 \quad(6.1)$ & $56 \quad(4.9)$ & $565 \quad(2.9)$ & $30 \quad(4.2)$ & $567 \quad(5.1)$ \\
\hline Finland & $11 \quad(2.7)$ & $576 \quad(5.3)$ & $87 \quad(3.0)$ & $564 \quad(2.1)$ & $2(1.2)$ & $-\quad-$ \\
\hline Russian Federation & $10 \quad(2.1)$ & $599 \quad(6.9)$ & $63 \quad(2.9)$ & $588 \quad(2.5)$ & $27 \quad(2.6)$ & $556 \quad(5.1)$ \\
\hline Lithuania & $8 \quad(2.1)$ & $555 \quad(6.0)$ & $\begin{array}{ll}66 & (3.6)\end{array}$ & $552 \quad(3.4)$ & $26 \quad(3.5)$ & $536 \quad(4.8)$ \\
\hline Germany & $0 \quad(0.0)$ & $-\quad-$ & $29 \quad(3.2)$ & $552 \quad(3.9)$ & $71 \quad(3.2)$ & $530 \quad(4.9)$ \\
\hline International average & $22 \quad(0.4)$ & $516 \quad(1.6)$ & $47 \quad(0.5)$ & $512 \quad(0.8)$ & $31 \quad(0.4)$ & $491 \quad(1.0)$ \\
\hline
\end{tabular}

The influence of the work of school principals on the achievement of the students also manifests as, for instance, initiation, organisation and/or maintenance of various support systems in their school. Within the PIRLS 2016 study survey, the Latvian principals answered a question regarding the additional support systems the schools have for the students, teachers and the parents of the students (Figure 1). A majority of the principals indicated that there were additional lessons available for the students for the improvement of their reading literacy as well as a support system for the parents and the teachers.

Support systems are available in schools with both high and low achievement in Latvia. The introduction and implementation of support systems in the schools does not suggest higher reading literacy results among the students, but is to be evaluated positively because it shows that the schools are interested in improving the reading literacy of the students and in providing the necessary support to the parents and the teachers.

The previously analysed data also confirm the conclusions drawn in other research studies that the association between the principal and the achievement of the students is indirect. The principal furthers positive changes in the school, and this improves the achievement of the students. Furthermore, if there 
are high expectations from the management in the school, the students try to fulfil such expectations (Cotton, 2013).

Do you have any of the following in the school?

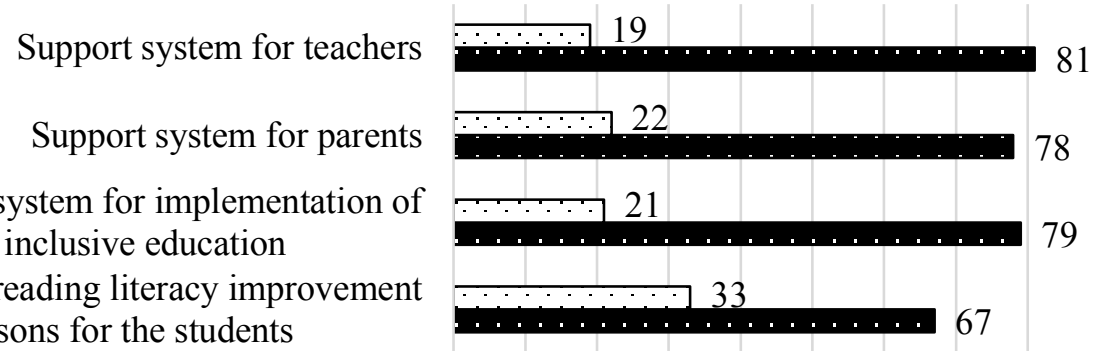

$\square$ No (\%) - Yes (\%)

$\begin{array}{llllllllll}0 & 10 & 20 & 30 & 40 & 50 & 60 & 70 & 80 & 90\end{array}$

Figure 1. Support systems for teachers, students and parents in the school.

When taking a look at to what extent the Latvian school principals agree with various statements regarding the student achievement, it can be seen that $44 \%$ of the principals have specified that they agree entirely and $54 \%$ of the principals have specified that they rather agree with the statement that they expect high achievement from the students of their schools (Table 7).

Table 7

Expectations of Latvian school principals with regard to the achievement of the students of their schools and the corresponding average achievement of the students

\begin{tabular}{|c|c|c|c|c|c|c|c|c|}
\hline \multirow[b]{3}{*}{ Statements } & \multicolumn{8}{|c|}{ How much do you agree with each of these statements? } \\
\hline & \multicolumn{2}{|c|}{ Agree a lot } & \multicolumn{2}{|c|}{ Agree a little } & \multicolumn{2}{|c|}{ Disagree a little } & \multicolumn{2}{|c|}{ Disagree a lot } \\
\hline & $\begin{array}{l}\text { Percent of } \\
\text { princi-pals }\end{array}$ & $\begin{array}{l}\text { Student } \\
\text { achieve- } \\
\text { ment }\end{array}$ & $\begin{array}{l}\text { Percent of } \\
\text { princi-pals }\end{array}$ & $\begin{array}{l}\text { Student } \\
\text { achieve- } \\
\text { ment }\end{array}$ & $\begin{array}{c}\text { Percent of } \\
\text { princi- } \\
\text { pals }\end{array}$ & $\begin{array}{c}\text { Student } \\
\text { achieve- } \\
\text { ment }\end{array}$ & $\begin{array}{c}\text { Percent of } \\
\text { princi- } \\
\text { pals }\end{array}$ & $\begin{array}{l}\text { Student } \\
\text { achieve- } \\
\text { ment }\end{array}$ \\
\hline $\begin{array}{l}\text { I expect high } \\
\text { achievement from the } \\
\text { students }\end{array}$ & $44(5.60)$ & 550 & $54(5.60)$ & 539 & $2(0.79)$ & 543 & $0(0.32)$ & 531 \\
\hline $\begin{array}{l}\text { I expect from the parents } \\
\text { of the students that they } \\
\text { will help the students } \\
\text { gain high achievement }\end{array}$ & $43(4.13)$ & 551 & $49(4.74)$ & 541 & $6(2.96)$ & 538 & $2(1.57)$ & 499 \\
\hline $\begin{array}{l}\text { Teachers know that high } \\
\text { student achievement is } \\
\text { expected from them }\end{array}$ & $54(6.16)$ & 545 & $41(6.55)$ & 545 & $4(2.44)$ & 526 & $0(0.32)$ & 531 \\
\hline $\begin{array}{l}\text { High student achievement } \\
\text { is a key target of the } \\
\text { school }\end{array}$ & $39(5.41)$ & 551 & $53(5.97)$ & 540 & $7(2.68)$ & 541 & $0(0.32)$ & 531 \\
\hline
\end{tabular}

The absolute majority of the principals in schools with both low and high achievement in Latvia agree with the statements regarding the achievement of the students provided in Table 7. Although there is a low percentage of the principals who have not agreed with these statements, it is still an indicator that the principals have not set high student achievement as a priority, but conditions are created in the school to favour them.

\section{Conclusions}

Based on the analysis of the role of the principals in high student achievement, it has to be emphasised that the role of the principal is significant in the facilitation of high student achievement, but the association of the principal with the achievement of the students is, however, indirect. The principal manages various processes in the school, favours circumstances which assure a successful learning 
process for the students, facilitate the professional activity of the teachers, and, consequently, improve the achievement of the students as well. As concluded in the research study, the experience of the principals has a weak association with the achievement of the students. In a school of an experienced principal, students do not always have higher achievement compared to a school with a less experienced principal, and, furthermore, a less experienced principal does not necessarily mean that the achievement of the students will drop.

Another significant indicator is the previous preparedness of the students when starting their 1 st year at school. A task of school principal is to create conditions to improve reading literacy among the students who have started their schooling without it and also support the teacher and facilitate their professional activity. The principal is, therefore, responsible not only for the assurance of the learning process, but also for focused support in the process of teaching and the activities of the teachers by building a support system or creating conditions that improve the student achievement.

The school environment built by the principal together with the teachers is also a substantial factor. For example, giving an opportunity for the students to do their homework at school by providing a place where the students can do it. However, there are no grounds for claiming that, in Latvia, the achievement of students is positively influenced by whether there is a suitable place for doing homework or any support staff who could help the students does it. However, it should be taken into account that it is a good practice and that principals should provide such an opportunity in the future as well.

It is essential that the management of the school expects high achievement from the students because this facilitates and improves the achievement of the students. The higher the expectations of the principal and the teachers, the more the students try to meet them. Therefore, school principals should build an environment and culture in their schools where all (the management, the teachers and the parents) have high expectations with regard to the achievement of the students.

\section{Bibliography}

1. Andersone I. (2013). Educational Institutions' Leaders Competences. In V. Dislere (Ed.), The Proceedings of the International Scientific Conference Rural Environment. Education. Personality (REEP), 6. Jelgava: LLU TF, 165-172. Retrieved from: http://lufb.llu.lv/conference/REEP/2013/Latvia-UnivAgricult_REEP_2013_ISSN_2255-808X.pdf

2. Brockmeier L. L., Starr G., Green R., Pate J. L., Leech L. D. (2013). Principal and School-Level Effects on Elementary School Student Achievement. International Journal of Educational Leadership Preparation, $8(1), 49-61$.

3. Cotton K. (2013). Principals and student achievement: what the research says. Alexandria, Virginia USA: Association for Supervision and Curriculum Development.

4. Dhuey E., Smith J. (2014). How important are school principals in the production of student achievement? Canadian Journal of Economics, 47(2), 634 -663.

5. Koch A. R., Binnewies C., Dormann C. (2015). Motivating innovation in schools: School principals' work engagement as a motivator for schools' innovation. European Journal of Work and Organizational Psychology, 24(4), p. $505-517$.

6. MK noteikumu projekts "Noteikumi par valsts pamatizglitibas standartu un pamatizglitibas programmu paraugiem" (Draft Cabinet Regulations "Regulations Regarding the State Standard in Basic Education and Examples of Basic Educational Programmes"). (2018). Retrieved from http://tap.mk.gov.lv/lv/mk/tap/?pid=40464178 (in Latvian)

7. Mullis I. V. S., Martin M. O., Foy P., Hooper M. (2016). PIRLS 2016 International Results in Reading. Retrieved from Boston College, TIMSS and PIRLS International Study Center website: http://timssandpirls.bc.edu/pirls2016/international-results/pirls/summary/

8. O’Malley M. P., Long T., King J. (2015). “What Do You Do All Day?!”: Navigating the Challenges of School Leadership as an Early Career Principal. Journal of Cases in Educational Leadership, 18(2), 107 - 121.

9. Purvins M. (2017). Factors Influencing Education Achievements in Latvian General Schools. Summary of the Doctoral Thesis, University of Latvia, 167.

10. Puzio, K., Newcomer, S. N., Goff, P. (2015). Supporting Literacy Differentiation: The Principal's Role in a Community of Practice. Literacy Research and Instruction, 54(2), 135 - 162.

11. Soehner, D., Ryan, T. (2015). The Interdependence of Principal School Leadership and Student Achievement. In Scholar-Practitioner Quarterly, 5(3), $274-288$. Retrieved from https://files.eric.ed.gov/fulltext/EJ974355.pdf

12. Ulf L. (2015). Professional norms guiding school principals' pedagogical leadership. International Journal of Educational Management, 29(4), 461 - 476. 